\title{
The social production of container space
}

Abstract: A sizable body of popular and academic literature explores how containers have reconstituted the spaces through which they travel. However, the space within containers remains largely unexamined. This article leverages the concepts of "earmarking" and "pressure" to analyze the space within containers as socially produced rather than arithmetically defined. The analysis draws upon an ethnographic study of container freight from China to Africa. Earmarking describes the practice of attaching segments of shipment space to specific sets of social relations, which in turn defines appropriate usage of the space and bestows it with economic value. African traders earmark space in containers shipped from China as a way to manage their capital in volatile economic environments. Logistics agents apply physical pressure to goods as they are loaded in containers in South China. The practice - made possible by the material characteristics of the container-disrupts the relationship between the container's measurements and the shipment volumes sold, and generates asymmetries across modes of calculating space. Application of pressure renders the relation between containers and goods unstable and shipments vulnerable during customs inspections. Opening the container space for analysis reveals how China's successful logistics integration with Africa relies heavily on political tolerance for disorder and localized solutions.

\section{Introduction}

The shipping container has become an object through which academics and non-academics alike imagine global interconnections. Container design prioritizes function over form; containers can hold large quantities, protect content from impact, and be stacked, moved, and redeployed to connect production and consumption sites across the world. However, critical logistics scholars are challenging the alluring idea of "the box" (Levinson, 2016) as an object autonomously changing the world economy. The politics involved with ensuring the circulation of the container are brought clearly into relief following threats of disruption, to which responses vary from erecting physical security structures around container ports to mobilizing power to dismantle the bureaucratic barriers against the transnational mobility of goods (Birtchnell et al., 2015; Cowen, 2014; Stenmanns and Ouma, 2015). 
While recent research illuminates how the shipping container structures and reorganizes relations across space, the space within containers is rarely recognized as a subject of analysis. The absolute qualities that define the container can get in the way of appreciating how the spaces within containers are socially produced. The container's height, width, and length measurements, as well as the quality of its steel walls and locking mechanisms, are precisely defined to ensure commensurability across space and transportation modes. However, standardization does not imply that the space within the containers is an absolute entity. Rather, a container's material characteristics generate the potential for a diverse use of container space. The space within the containers is reorganized as it moves around the world, both reflecting and shaping the social relations at the places it connects. Analyzing how the space within containers is used can clarify the social orders of long-distance circulation. Conversely, the expanding body of critical scholarship on the global circulation of goods provides analytical lenses through which studies on the production of space within containers may be viewed. The present study interrogates the production of container space by drawing upon ethnographic data about logistics in small-scale trade from China to African countries.

The concepts of "earmarking" and "pressure" provide analytical entry points for understanding relations between the production of the interior space of containers and the production of transnational trading spaces. Earmarking denotes the attachment of resourcesin particular, the seemingly neutral means of exchanging money-to social relations that prescribe how these resources may be used and circulated (Zelizer, 1994). Pressure encapsulates how stress transmits between physical, political, and economic domains as actors shift the strain toward new groups and fields (Anand, 2011; Tsing, 2015). Both concepts link micro-social interaction to larger political orders in ways that can be brought to bear on logistics scholarship.

The first section of this paper considers how the concepts of earmarking and pressure can open up theoretical analysis concerning the space within containers. The following section discusses the empirical context of the present study and the use of ethnographic data about logistics between production lines in China and distribution in African end markets. The third section employs the concepts of earmarking and pressure to analyze container-based trade. Standardization has made the container an object of aspiration and achievement, while simultaneously representing a constraint in China to Africa exports. Traders use earmarking to manage uncertainties. Finally, applying pressure to container-shipped goods has disrupted the relations between units, bringing down shipment costs while simultaneously enhancing the 
importance of political connections in logistics. The conclusion highlights the high political tolerance for disorder that has made the expansion of China to Africa exports possible.

\section{Opening the container to analysis}

The defining feature of the shipping container is its uniformity. The global fleet of dry containers are equivalent in size and specifications, and hold a combined volume of 30 million 20-foot equivalent units (TEU) (World Shipping Council, 2018). The World Shipping Council, which represents most of the global liner shipping industry, highlights the immense amounts of goods transported around the globe, the advanced technology employed in these movements, and the efficiency with which goods are moved as a result of standardization. The moving container ship and the physical vastness of container ports offer concrete sensory impressions through which the enormity of global capitalism may be grasped. However, the same images may easily mask capitalism's heterogeneity and the labor that goes into producing and moving things (Gregson et al., 2017; Tsing, 2009). Opening the space within containers to analysis provides a method for acknowledging the container as both a force for rationalization and a device that allows for diverse applications and entails the potential for disruption.

The container itself is often written off as uninteresting - it "has all the romance of a tin can," as the author of best-selling volume The Box put it (Levinson, 2016:2). When subjected to analytical scrutiny, however, the container is a productive lens for examining economic phenomena. Empty containers that pile up in the economic periphery articulate the geographic unevenness in manufacturing activities. The containers' usefulness for holding goods turns into awkward bulkiness when incoming containers are emptied and accumulate because there are no goods to load for export (Neilson, 2015). Analyses of how goods are held together by containers highlight how containers organize the encounters between diverse bodies in a predictable manner, but also the vulnerability produced by standardization. The closed and uniform nature of containers involve the possibility that they hold smuggled wares, stowaways, or even terrorist bombs, which highlights that standardization is a reversible achievement. Desires to control what containers carry must be balanced against the need to move goods along the supply chain (Cowen, 2010a; Nordstrom, 2007). When containers were introduced, they improved security (mainly against theft), whereas currently, container shipment is regarded as a serious global security threat (Levinson, 2016).

Beyond being a moving thing and a mover of things, the container is a spatial formation produced through the practices and relations of human and nonhuman actors (cf. 
Thrift, 1996). The nature of these encounters changes as the container circulates the world. The most evident change is the different economic value attributed to the space depending on where the container is located and its potential onward routes. Social relations and material connections shift and multiply as the container space traverses distances, inviting new possibilities for putting the space to use. To avoid fetishizing the space within containers, as well as the space containers are moved across, cargo mobilities may be approached as actions located with a broader universe of social and material connections (Steinberg, 2015). The power implicated in the movement of cargo ensures regularity in how it circulates; "certain forms of space tend to recur, their repetition a sign of the power that saturates the spatial" (Rose, 1999:248).

The social production of the space within containers expresses the power implicated in making things circulate. Logistics represents space- and scale-making that smooth the movement of commodities across space (Danyluk, 2018). In examining the specific ways the space within containers is produced, and how it links with the production of the spaces the containers travel through, the concepts of earmarking and pressure provide productive analytical tools. Analyzing earmarking practices de-fetishizes the space within containers by interrogating the social relations that produce space and are influenced by the ways space has been produced. Analyzing pressure brings into view the socially malleable qualities of space, and how spatial outcomes are volatile and retain the potential for reversal.

\section{Earmarking}

Earmarking denotes the dedication of a specific resource for a particular purpose by attaching it to certain social relations. With this concept, anthropological and sociological studies have questioned the common assumption that individual units of money are interchangeable.

Earmarking may similarly open to examination other resources that tend to be understood as uniform, including container space. The container resembles money in important ways. Like the coin, the container travels the world, has a standard shape, and is valued for the ways it is put into circulation rather than for its physical qualities.

Earmarking money was first studied by examining the ethnographies of currencies. These studies contrast traditional currencies reserved for specific purposes with currencies of modern societies, which are supposedly unburdened by rituals and constrictions (Bohannan, 1955; Dalton, 1965). Recent reassessments of traditional currencies have challenged conclusions concerning restrictions on their use. Guyer (2004), who has reexamined the spheres of exchange among the Tiv in Nigeria, demonstrates that the boundaries between 
currencies were more permeable than initially thought because equivalence could be achieved by circulating commodities in regional trade systems when a direct conversion was deemed socially unacceptable. Thus, regional trade enabled conversion between low- and highprestige items in both directions (Guyer, 2004:31). Furthermore, gains could be extracted by playing on the disjuncture between multiple coexisting systems of value. Within this system, asymmetry in exchange was understood and expected, rather than masked by ideas of equivalence, as in contemporary market societies (Guyer, 2004:40).

Multiple currencies are not a necessary condition for money to be earmarked. In psychology and microeconomics, scholars working within Western contexts have noted that spending behaviors are influenced by how people mentally code gains and losses (Thaler, 1985). While economists depict mental accounting as irrational because it produces suboptimal results, anthropologists and sociologists have approached the multiple symbolic meanings of modern money as an integral aspect of social life (Parry and Bloch, 1989). Zelizer's (1994) book The Social Meaning of Money catalogs different types of social interaction and the relevant earmarked monies. People employ many conceptual, legal, and organizational techniques, ranging from fruit jars to trust funds, to distinguish between various monies. Distinctions and directives that defy instrumental calculations are conspicuous in the case of money because money is commonly assumed to represent depersonalized and rational exchange. Writing against such fetishization, Latour (1990:20) argues that money "has been thought of as something special, deeply inserted in the infrastructure of economies, whereas it is just one of the many immutable mobiles necessary if one place is to exercise power over many other places far apart in space and time." Containers and container space have arguably been attributed a similar, fetish-like quality (Birtchnell et al., 2015).

As a social practice, earmarking can engender disputes when parties assess a situation differently, pursue opposing interests, or subscribe to conflicting values. Sociological research studies concerning money are rich in accounts of conflicts over the proper use of specific funds (Zelizer, 1994). Parallel arguments concerning the socially acceptable use of space were made in a recent study of container shipment from Europe to Nigeria (Jedlowski, 2016). The study chronicles how a container shared by a Nigerian migrant couple in Italy became the object of tense interactions between the migrants' extended families. The couple had achieved what many of their Nigerian peers aspired to-shipping home a container full of goods. The man shipped electronics and two vehicles in the container; the woman shipped tomato paste, clothes, and shoes. Both assumed that the proceedings from the sale of these goods would 
enable them to set up businesses in Nigeria and move home with their firstborn child. However, once the container reached Nigeria, the couple's families started questioning how to divide its contents. These conflicts were exacerbated when the container got trapped in customs, and goods had to be extracted and sold to pay customs agents. While the man was stuck in Italy, waiting for his residence permit, he began to question his fiancée's ability to deal with the container import. He eventually also doubted her intention to honor their understanding concerning how the goods would be divided. Although earmarking the goods in the shipment had seemed straightforward at the outset, conflicts over the moral legitimacy of the claims to those goods created irreconcilable differences. Furthermore, the social contract established between two people was permeated by several other social relations. Instead of being a vehicle for achieving the couple's long-term goal of building a life together in Nigeria, the container eventually precipitated their breakup.

Container space may, like money, be used as a material means for storing value. Research on just-in-time production has documented how container transport has become a means for storing goods by holding inventories in slow motion rather than leaving them in place-bound storage (Coe, 2014; Gregson et al., 2017). For African traders, holding liquid assets is often associated with a heavy pressure to redistribute them (cf. Smith, 2001). By keeping goods in motion, traders can tie up wealth and ensure they are not holding large amounts of money that others may feel entitled to claim. This is not to discount the contributions of traders to the larger community. As goods are converted into money, these funds often contribute toward school fees, hospital bills, and other social expenses for a wide group of people. Resources that trickle in steadily as small batches of goods help traders retain business capital. Earmarking money and space in combination provides traders with more control over social spending.

\section{Pressure}

While earmarking helps researchers understand how people deal with the inherent instability of logistical orders, pressure is a useful analytic for examining how such instability arises and is maintained. Pressure implies that relations, whether material or social, are placed under stress and, therefore, have the potential to shift. Recent work in urban geography has addressed the relationship between material infrastructure and social and political formations (Kaika, 2005; Rest, 2018; Swyngedouw, 2004). Anand (2011) introduces the concept of "pressure" to examine this relationship in research related to water access in Mumbai. Manipulating pressure makes water available to diverse social groups. Access to piped water 
both signifies and results from political belonging. However, such belonging cannot secure belonging indefinitely for marginalized groups: Hydraulic citizenship must be renewed through an iterative process that relies on repetition and revalidation. Physical pressure is mobilized for water to flow through pipes and into households. When water pressure is unacceptably low, citizens generate political pressure to make claims on the city's infrastructure. As water is diverted to new groups, political discontent builds up in disadvantaged areas, where people, in turn, reapply political pressure to access water. Through the notion of pressure, the city can be apprehended as a social, political, and physical assembly simultaneously.

Logistics under just-in-time production systems strive toward keeping goods in motion (Cowen, 2010b). Contemporary distribution centers designed to perpetually keep goods moving contrast with traditional warehouses that store stocks of goods (Cidell, 2015). For capital in the form of goods to flow unobstructed, other capital must be embedded in the form of infrastructure. For example, the smooth travels of container-carried goods are enabled by massive, place-bound investments at every link in the cargo chain (Danyluk, 2018). China's logistics expansion has inspired both admiration and wariness in other countries. Africa's logistics infrastructure, by contrast, has been characterized by international institutions as a bottleneck in global cargo circulation because it is inefficient, unreliable, and wanting (Stenmanns and Ouma, 2015; World Bank, 2016).

When the steady movement of goods is disrupted, pressure builds. Containers pile up inside African ports, where cargo dwell time is longer than anywhere else in the world (Refas and Cantens, 2011). African politicians and bureaucracies are, in turn, under pressure by international agencies to instigate reforms that will increase the amount of TEU that their ports can process (Chalfin, 2010; Stenmanns and Ouma, 2015). As in the case of water piping in Mumbai, points of translation exist between the physical and political pressure; when containers amass in their ports, African governments are pressured by international organizations and their counterparts to improve their ports' capacity to sustain flow.

Pressure may be deferred and displaced along the routes containers travel. Repairs at one site can create blockages elsewhere. The loading and unloading of containers represent critical junctures in efforts to maximize logistics infrastructure utilization along the route. Gregson et al. (2017) describe how, as a result of efforts to take advantage of the container's carrying capacity, costs were transferred downstream in the logistics chain. A container load of polyethylene plastic bags shipped from Ningbo, China, was opened at its destination in rural England, where those in charge of unloading realized it was stuffed with small, 
unconsolidated cardboard boxes. Two manual workers managed, with significant physical exertion and under duress, to empty the container just in time to avoid demurrage charges. In this case, the pressure was absorbed through physical toil during unloading. In other instances, truck drivers absorb the pressure, whether through exposure to greater health and safety risks or through compulsory roadside stops for rest following delays in containers' departures (Gregson, 2017).

The capacity for redirecting pressure onto other actors in the form of both lower profit margins and higher risks characterizes global supply chains. As Tsing (2009) demonstrates, the cost-cutting power of supply chains rests largely on making independent contractors assume higher costs and accept fewer benefits. To understand how this is possible, one must look to the cultural and social foundation for self-exploitative practices among the suppliers of goods and services. Various groups attach their identities to specific socioeconomic niches, placing a high value on being self-employed business owners, which, in turn, makes them prone to absorbing costs and contributing to the downward pressure on prices (Tsing, 2009:168). Precarity is not an exception under the current form of capitalism; rather, vulnerability resulting from living between shifting assemblages is integral to how capitalism currently works (Tsing, 2015). By extension, pressure emerging at various points along logistical chains will not dissolve, but take on novel forms and relocate toward new actors.

\section{Context and methods}

South China has been a center for global trade since pre-modern times (Wyatt, 2010). At the pinnacle of the British Empire, Hong Kong emerged as an entrepôt in trade between Asia and Europe (Ho and So, 1997). After the People's Republic of China was established, Hong Kong industrialized and became a site for production as well as trade. The post-1978 Chinese reform policies allowed Hong Kong manufacturers to move production into Mainland China, where land and labor were cheaper (Smart and Smart, 1991). For two decades, Hong Kong occupied a position as an intermediary in the trade between the People's Republic of China and the rest of the world, and goods produced in China were exported through the Port of Hong Kong. However, deep-water ports have been constructed on a massive scale over the past decades and China is now home to seven of the world's ten largest ports. Guangzhou and Shenzhen and compete with the Port of Hong Kong to ship goods from China to the rest of the world (World Shipping Council, 2018). China's Belt and Road Initiative (BRI), through which the construction of roads, rails, ports, and pipelines will improve connections between China and Central Asia, Europe, and Africa, represents a continuation of four decades of 
heavy investment in trading infrastructure. Logistics infrastructure has only recently been assigned a central place in discourse about the Chinese national identity, but the BRI represents an extension of long-established policies for using infrastructure to support export growth.

The first African traders set up their businesses in Hong Kong in the late 1970s (Bertoncello and Bredeloup, 2007). Today, most traders bypass Hong Kong and fly directly into Guangzhou in Mainland China (Haugen, 2018). In 2016, China registered 589,000 overseas arrivals by nationals of African countries, most of which were into Guangdong Province (National Bureau of Statistics of China, 2017). African traders travel to the provincial capital of Guangzhou to procure goods and acquire information about new styles and types of products in the city's many wholesale markets (Mathews et al., 2017). Trade between China and African countries has increased rapidly over the past decades, and China became the African continent's largest trade partner in 2009 (UN Comtrade, 2018). Except for South Africa, import and marketing in African countries are not dominated by multinational retail corporations (A.T. Kearney, 2015). Successful logistics integration in exporting from China to Africa has been achieved as much through a high tolerance for disorder and localized solutions as by way of centrally devised economic strategies.

The present research analysis draws upon 16 months of ethnographic fieldwork between 2009 and 2016 in South China, as well as shorter data collection periods in the Makola market (Ghana), along the Nigerian section of the trans-West-African highway, Eastleigh market (Kenya), and the two West African regional trading hubs of Lomé (Togo) and Banjul (Gambia). Logistics originally had a cameo role in this fieldwork, which was focused on how profit was made and captured along value chains for goods produced in China for African end markets. However, from October through December 2009, I was based in a logistics office run by a Chinese and Nigerian who, respectively, focused on air cargo and the purchase and sale of extra luggage space. When recruiting informants for my research among their customers, I observed how logistics was employed in innovative ways to suit the business model and social context traders and factory owners operated within. I subsequently assigned a more central role to sea- and air-based logistics during data collection on exports from Guangzhou between January and December 2014.

The methodological approach in this research is inspired by global ethnography, which applies an ethnographic microscope to enrich theories about global processes from the ground up (Burawoy and Verdery, 1999). The global ethnography field is defined empirically through the spatial reach of the processes and social relations at hand: Relations do not merely 
play out in space, they are space-making. In this research, I started by conducting participant observation in the logistics offices of West and East African agents in the center of Guangzhou. The fieldwork then extended to the warehouses used by these agents on the outskirts of the city. I reconnected with the agencies at their warehouses in Lagos, Nigeria, and Nairobi, Kenya, from which they distributed the shipments to their customers. I also followed traders who exported goods from China to their home countries and conducted semistructured interviews with providers and users of logistics services from South China to African cities. The analysis takes a "logistics-in-action" approach that considers logistics as a provisional achievement (Gregson et al., 2017; Steinberg, 2015).

Names and identifying details have been changed to protect the anonymity of the research participants.

\section{The logistical foundation for China-Africa export}

The mobility of goods from South China to African markets does not arise as a mere effect of demand, supply, and price differences. The fast growth in direct exports from China to Africa followed the establishment of logistics systems adapted to specific economic and social contexts. African traders operate in unstable economic and political environments, often with limited capital, and have relied upon logistics agents in China to creatively tailor the scale and rhythm of container-based circulation to suit their needs. The agents employ logistics infrastructure that was established as part of Chinese politically sanctioned projects, including investments in maritime structures, air cargo ports, and the integration of air-, sea-, and landbased transportation modes. The logistics agents appropriated this physical infrastructure and invested in relations with customs officers to enable such adaptations. The authorities in Guangdong Province have so far tacitly accommodated informal freight brokers. The evolution of logistics systems from China to African countries demonstrates that the space within containers is neither pre-formed nor stable, but rather an expression of social relationships. Mobility produces certain trading spaces, and opening the space within containers to analysis elucidates how.

The discussion below outlines how the logistical foundation for China to Africa exports has evolved. When the first African traders sourced goods in Mainland China, logistical constraints turned the container into an object that indicated wealth and strong transnational relations, resources sought-after by many and attained by few. Later, the introduction of less-than-container load (LCL) shipment reorganized logistics in ways better adapted to the economic and social context many African traders operated within, which 
formed the foundation for increasing the volumes traded from Mainland China to African markets.

\section{The container as an aspirational object}

Containers hold symbolic, as well as financial, value. To fill and ship a container requires a certain amount of capital. The fixed size of the container associates it with the kind of financial achievement traders aspire to and people around them readily recognize.

Logistics infrastructure in Hong Kong made it possible for African traders to share containers in the 1990s, each loading his or her own goods. The lack of such infrastructure in Mainland China represented a key competitive advantage for trading agents based in Hong Kong. Chinese manufacturers were interested in cutting these Hong Kong intermediaries out of their deals. In order to achieve this, the manufacturers occasionally offered traders credit to buy a full container load of goods that they could ship home directly. Seydou, a Guinean businessman, was one of the African traders whose trading careers was advanced through such a loan. He had already made a few trips to Hong Kong to buy footwear when he first ventured into Mainland China in 1998. He quickly realized that the shoes sold by factories there were much cheaper than those he bought via agents in Hong Kong, but he did not have enough money to fill a container. A factory owner offered him credit to ship a 20-foot container to Guinea. The shoes arrived safely, and Seydou sold them fast and reimbursed the factory. Sixteen years later, Seydou had become a wealthy trader for whom shoes represented a minor line of business, but he still bought footwear from the factory owner who once entrusted him with more capital than she could afford to lose. In his accounts of his paths to success, the first full container shipment represented a defining moment.

While cargo ships travel to their destinations, the value of the goods they carry is unavailable. Thus, the net worth of traders can be deduced from the number of goods they have locked up in containers. "He now had four containers at sea. I am telling you, he has [made it] big!" a Nigerian pastor in Guangzhou said about a former congregant. A container is also a unit for articulating financial aspirations. The pastor prophesized to a cheering crowd of congregants, "Chinese factories will be calling you when you are asleep begging to give you credit. You will say no to the factory calling to give you 120,000 RMB credit because there is another that is giving you credit for ten containers!" Presented in this way, the container is not merely a means of transporting material objects that enhance the economic and social status of the owners; it is itself a marker of success. Shipping containers are aspirational because of their size and capital requirements. At the same time, these qualities served as barriers against 
direct trade from Mainland China to Africa. The introduction of LCL shipment in Guangzhou changed this, as discussed in the following section.

\section{Partitioning container space through groupage}

The establishment of logistics agencies in Guangzhou that offered LCL, locally dubbed “groupage," propelled exports to Africa. It also reconfigured who could become long-distance traders, where they traveled, and what they accomplished. Cheap, low-volume shipping options enabled traders with less than 5,000 USD capital to order customized products from small, low-tech factories around Guangzhou and ship them directly from China. Even wealthy traders may prefer groupage over full container loads to mitigate risk, sustain a diverse product portfolio, and introduce merchandise to the market at different times. Whereas shipping full containers allows others to quantify one's wealth and know when one has assets available, shared shipments are less conspicuous. Combined with cheaper and more frequent passenger flights, the possibility of shipping by sea at low rates regardless of capital and contacts has made trading accessible to new groups. The figure of "the trader" is consequently reimagined. A common complaint put forward by wealthier merchants, discontent that their status, as well as their market shares, has come under threat, is that "everyone is a trader these days." This development illustrates how logistics "makes its subjects anew" by composing and altering the parties it brings into relation (Neilson, 2012:337).

Groupage renders container shipment more flexible by altering the unit of calculation for shipping space from container loads to cubic meters. Logistics agents commission full container shipments from Chinese to African ports, and sell space within these containers to traders according to their shipping volumes. They receive goods from clients and bundle them for shipment. Once they amass enough goods to fill a 40-foot container, a truck backs a container into the warehouse and loads pre-packed goods in less than an hour. Next, the container is sent to either the Nansha or Huangpu port, together with a packing list that itemizes the load. Logistics agents are usually responsible for clearing customs both when the containers leave China and when they arrive in African ports. At both sites, the container may be opened to compare the content against the packing list and check for illegal and counterfeit goods. Customs clearance is particularly complicated for LCL shipments, for which there are numerous ways to define the value of the load and quantify import taxes (Refas and Cantens, 2011). The logistics agents often employ clearing agents to get the goods through customs in African ports. The clearing agents may be unregistered businesses that request licensed companies to lodge declarations in their name or use their connections to deal with customs 
officers (Cantens et al., 2014; Schwarz, 2006). Once the goods are brought through customs, they are transported to warehouses for pickup by the customers.

One of the first groupage agencies in Guangzhou was started in 1999 by a Chinese woman, who had taken the name Mary, and her Nigerian acquaintance, Chibuzo. Mary had left the People's Liberation Army two years earlier to work for a Chinese logistics company in Guangzhou. She encountered one of the few Nigerian traders coming to the city at the time, and she helped him locate manufacturers. To expand her network of potential customers, Mary started frequenting a Nigerian-led church, where she met Chibuzo. He proposed that they establish a partnership to set up groupage freight from Guangzhou. He knew how to clear the goods on the Nigerian side, while Mary could take care of the communication with the shipping line and customs in the Chinese ports. They founded God's Way Logistics with a modest capital of 2,500 USD, and commissioned a container, recruited customers, and cleared the goods in Nigeria. God's Way had few competitors and flourished. The company is now one of the largest of several hundred logistics agencies in South China that ship to Africa.

The initial destinations for groupage shipments from China were Lagos and Port Harcourt in Nigeria and Cotonou in Benin. Cotonou was a point of transit to circumvent import bans and high taxes in Nigeria under the Obasanjo government (1999-2007). The goods were transported into Nigeria via the Cotonou-Lagos highway or across the border with Niger in the north, where checkpoints were less frequent and informal duties lower. Around 2010, when Goodluck Jonathan was elected president in Nigeria, import bans were lifted, and Nigerian logistics agents no longer shipped goods via Cotonou. As the group of traders who traveled to China grew more diversified, logistics agents started shipping to ports across the African continent.

Groupage logistics in Guangzhou largely emulated the logistics agencies already in place in Hong Kong and Dubai, the main distribution points for Asian exports to Africa (Feenstra and Hanson, 2004; Sigler, 2013). However, the China-based logistics agents offer a broader range of services, allowing traders to customize goods in addition to shipping readymade products. The agents help traders identify manufacturers, review prototypes, and inspect deliveries before shipping the merchandise. They seek to pull together bands of loyal customers by turning their logistics offices into social spaces, offering beverages, meals, and internet access. Like the matsutake mushroom buyers courting mushroom pickers described by Tsing (2015), logistics agents know that customers represent an evanescent asset: Traders are quick to leave if they sense that another agent ships goods more effectively, trusts them with additional credit, and shows more care for their wellbeing while in China. 
The articulation of Guangzhou as a logistics hub in China to Africa value chains has entailed disarticulations (cf. Bair and Werner, 2011). In particular, many Hong Kong-based wholesalers, factory representatives, and logistics providers have been made redundant. There are exceptions: The transport of illegal goods, particularly copies of brand-name products, still moves through Hong Kong because counterfeits pass customs at ports and air terminals more easily there (Mathews, 2015). The goods are brought from factories in China into Hong Kong by truck. Logistics agents can predict the cost of clearing customs for both legal and contraband goods, and offer traders fixed prices for shipping merchandise in the two categories. For example, a logistics company shipping goods to Nigeria quoted two prices on one of their flyers from 2009: Customs clearance for air-carried, non-contraband goods cost 80 Nigerian Naira (NGN) per kilo, whereas the equivalent charge for contraband goods was 280 NGN per kilo. Thus, logistics contribute to institutionalizing informality.

The warehouses of groupage agents enable direct orders from the factory. They are inbetween spaces where goods are neither in the custody of the trader nor the factory owner. Located on the outskirts of Guangzhou, where trucks can enter unobstructed, warehouses receive goods from factories once orders are completed without requiring the trader's presence in Guangzhou. The factories can also hold off deliveries until the trader has completed the agreed-upon payments. As a permanent and concrete link between traders and suppliers, the warehouses afford both parties flexibility and security. Logistics agents can be called upon to mediate in instances of conflict between traders and suppliers.

Groupage as a specific logistics assembly is inextricably linked to the financial organization of China-to-Africa exports. Large international logistics companies in South China generally require customers to pay all costs up front, including import tax and duties (Wang and Cheng, 2010). Groupage agents, by contrast, often prepay import tax and duties on behalf of their customers, and may even allow traders to sell some merchandise before completing payment for shipping. The informal credit extended by logistics providers is essential for African traders, who rarely have access to formal bank loans. Credit in petty commodity trade structures the relationships between businesses along the value chain by placing vertically related businesses in situations where they are mutually reliant on each other (Haugen, 2017).

\section{Earmarking: Differentiating container space}

Groupage can be understood as an earmarking practice. Logistics agents sell space within containers, and as they partition the container, specific social expectations are attached to each 
of the divisions. Examples of expectations traders have when they buy shipping volumes include help with practical problems while in China, credit during periods of financial hardship, free freight for single items, monetary bonuses following large orders, and concern for their general wellbeing. The types of expectations vary between clients, and some logistics agents described managing such expectations as more taxing, practically and emotionally, than the work of shipping goods. The CBM ordered by the trader and the money she pays are countable, but these numbers contain what has been termed "moral remainders" (Guyer et al., 2010:38): Something inextricably linked to the numbers that cannot be accounted for by equivalence but must be acknowledged for transactions to take place. Some logistics providers acknowledge the remainders through institutionalized practices. For example, one agent gave traders year-end monetary gifts corresponding to the number of CBMs they shipped, while another converted the CBMs sold into tickets for a raffle where traders could win motorcycles. Traders judged the character of the logistics agents by how they acknowledged these moral remainders.

Earmarking container space in groupage shipping is accounted for in the agents' written accounts of CBMs sold. By contrast, though the mental earmarking by traders who commission full containers is rarely recorded in writing, it provides them with a robust tool for dealing with social, economic, and political uncertainty and expectations. Through earmarking, traders divide the physically homogenous space within a container into separate segments and impose different principles for governing how these sections are used. Often, the traders in this research were remarkably articulate about how they mentally partitioned the container space. The central role earmarking played in the traders' business practices is best demonstrated through a specific example. The remainder of this section accounts for how a Senegalese trader partitioned the internal space in a 40-foot container and attached to social relations that structured actions to its various sections.

Bintou was a middle-aged woman from the suburbs of Dakar who was proud of how she had built a career as a businesswoman from a humble start. She liked to talk about the virtues of then-presidential-_candidate Hillary Clinton, who stood by her unfaithful husband to secure the family's future. Bintou described herself as a quiet person who was in China to do business, not to fool around. To illustrate her point, she identified a young Gambian man who had attempted to gain her attention to offer sexual intimacy in return for gifts; Bintou expressed disdain for women who allowed such men to court them.

Bintou's self-identification as a family-oriented person was central to her descriptions of how she managed to secure the sustainability of her business without jeopardizing social 
relations. Like many African traders, she was expected to bring gifts when she arrived home from China. Such gifts can deplete the business capital of traders who fail to show restraint. She had resolved not to bring more gifts than could fit in her suitcase. Bintou also announced that, as a woman who valued a frugal lifestyle over flashy displays of wealth, buying presents for her close family sufficed. The combination of spatial restrictions, gendered identity, and moral framing allowed Bintou to restrain her expenditures on presents.

A Senegalese logistics agent contracted the container on Bintou's behalf, and she delivered the goods she purchased to his warehouse. Bintou mentally partitioned the space in the container before she started the procurement. She reserved one section for goods that allowed her to recover travel expenses. This section was, in part, filled with China-made textiles that would pay for her plane ticket and visa. She would sell these to a wholesaler in Dakar who distributed the cloth to retailers and repaid her in weekly installments within the space of a month. She reserved another section in the container for recovering the costs of accommodation and living expenses in China. This space was filled with tampons and mattresses, goods that, like the textiles, had low but predictable profit. The money Bintou received after selling the textiles, tampons, and mattresses would be set aside to fund her next trip to Guangzhou.

The remaining space in the 40-foot container was designated for furniture and household appliances, which Bintou imported and sold on credit to people living in her suburb. This business yielded more profit than textiles and sanitary products, but the returns were slower and risks higher. Bintou gave customers furniture pieces one at a time, for which they paid 325 CFA (0.56 USD) every day through a credit plan. "That is not a lot, but in a month, it makes 9500 CFA. If you have many clients like that, it adds up to millions per year," she explained. She had recently struck a deal with a landowner in her community that would expand her group of customers. This time, she filled the container with bathroom fixtures, living room furniture, television sets, refrigerators, and air conditioners. Similar furniture payment plans have served as avenues for financial inclusion in many parts of Africa, particularly among black South Africans (James, 2014). Affordable container shipment makes such schemes viable for China-made goods.

At first sight, Bintou's earmarking of space may come across as a way to separate the resources allocated to social reproduction (the suitcase) and those allocated for business purposes (the container). However, just as anthropologists have demonstrated that distinctions between social and profit-oriented spending are fluid (Parry and Bloch, 1989), the space earmarked by Bintou does not fit neatly into one category. When asked if she included 
something for her housemaid in the suitcase she devoted to gifts to family members, Bintou replied, "Of course! I have to." She went on to explain that her business trips were only possible because she trusted the maid's ability to take care of the household in her absence. In other words, the social act of gift-giving was necessary for Bintou to keep her economic independence. Furthermore, Bintou's economic ventures were enabled by her social respectability. The arithmetic practices by which Bintou allocated money and shipment space for various purposes included both monetary and social variables. She presented her retailing plan as a development scheme for women in her hometown that allowed them to realize aspirations of a middle-class lifestyle, and she established a non-governmental organization for women and community development affiliated with the business. The shipments of furniture enabled Bintou to reproduce and strengthen her community relations purposefully.

The thriving furniture industry in South China relies on imported hardwood. Some of the wood originates in Casamance in Senegal, which is illegally exported to China via Gambia. Ironically, therefore, the furniture Bintou imported from China may have derived from wood that was once shipped in the opposite direction. However, the case also illustrates how unevenly balanced flows of exports and imports can involve shipping containers being employed in seemingly ineffective ways. Open-topped containers are built for easily loading and stacking lumber but were not used for the wood from Casamance. 40-foot shipping containers lined with plastic have recently been appropriated to transport agricultural products from North America to Asia because trade imbalances yield low westbound freight rates for closed containers (Levinson, 2016:364). The ban against hardwood export represents an additional reason for shipping round lumber in closed containers. The illegal export of hardwood can be concealed due to the ubiquity of closed containers keeping the goods they store out of view. Two-way container trade between China and Senegambia decreases the freight costs for traders like Bintou, but these legally sanctioned global cargo mobilities are entangled with illicit movements of cargo (cf. Martin, 2015; Nordstrom, 2007).

\section{Pressure: Rearranging spatial relations}

Hundreds of African groupage agents in Guangzhou compete for customers. They face pressure to ship goods cheaply, lest the customer take her business elsewhere. To offer traders cheaper shipping, logistics agents began investing in balers - machines designed to crush and compress scrap metal. Balers are employed to compress goods, especially clothes, before the bundles are measured. This allows more pieces to fit into each CBM, thus enhancing the value 
of the space within the containers and decreasing the traders' shipping costs. The pressure to sustain profits and ship goods effectively is thereby transmitted onto the goods themselves.

During the compression process, an ear-piercing sound fills the warehouse. Buttons, plastic adornments, and other pieces occasionally break loose under pressure, bursting out of the packages and endangering warehouse workers and onlooking traders. Next, the merchandise is wrapped in tarpaulin sheets held together by packing strips. The traders' names and phone numbers are written on the bales. "What's your marker name?" logistics agents ask traders, who often prefer to use aliases to avoid identification by competitors who catch a glimpse of their bales in warehouses.

Logistics affect production processes and styles. In the trading malls catering to Africans, clothing suppliers ensure that the goods on offer can handle crushing pressure. Traders want shirts with traditional buttons rather than unreplaceable snap fasteners and prefer embroidery to metal decorations. Only fashionable, high-quality items justify container shipment where no pressure is applied - or even air cargo transportation. The low profit margin on clothes made for mass consumption demands that African traders, like multinational fashion companies supplying clothes to Europe, minimize costs in all links, including shipment.

Garment traders find mannequin wholesalers next to apparel suppliers in Guangzhou. Chinese traders in Africa import containers full of mannequins directly from the producers for resale, yet some African traders prefer to buy them in Guangzhou. For logistics providers, the mannequins represent the garments' opposite: They are bulky, irregularly shaped, brittle, and - often to the customers' surprise - more expensive to ship than to procure. At a company catering to Ghanaian customers, female garment traders who had bought mannequins kept returning to the logistics agent to haggle on the shipping price. They accepted the company rate per CBM but asked that the amount of CBMs charged for the mannequins be lowered, threatening to take all their logistics orders elsewhere unless the logistics agent conceded. With no opportunity for transmitting this pressure to the commodities by compressing them, the agent saw no other option but to bill for a lower CBM count than the mannequins occupied and shipped the mannequins at a loss.

The baler compresses the goods into cuboids with slightly bulging sides. Logistics agents charge traders according to the volumes of their bales, calculated based on their widest points. An employee measures the height, width, and depth of the bales, sometimes in front of the customer, showing the numerical values on the measuring tape in a theatrically exaggerated fashion. Due to the irregular shape of the bales, differences occur in the volume 
traders pay for and the actual volume the bales contain. This discrepancy provides the logistics agent with opportunities for gains. After the bales are stacked into the container, a forklift presses them together. The pressure causes the bales to shift and fill any empty spaces. By exploiting the spaces between bales, the logistics agent can charge for higher volumes than the containers hold. One logistics agent pointed out that the margin between the calculated and the actual space was where he found it possible to make a profit; noncompressible goods, such as electronics and furniture, allowed him only to recover expenses. Creating and employing disjuncture in measurement scales as a means of profit has a long history in Atlantic Africa, as described in Guyer's book Marginal Gains (2004). Ordinal scales with socially agreed-upon threshold values create opportunities for gain when numbers on a continuous scale are matched with them (Guyers, 2004:51-60). In the case of ocean carriage, the containers represent the ordinal scale (TEU), while the volume of the bales is on a continuous scale.

The marginal gains generated through the shuffling of bales are lost if a container is intercepted for inspection at the Chinese port. Hodan, a logistics agent shipping to Kenya, complained that the port authorities would lift goods back into the container after inspection but stack them without applying any pressure. "When they close it, they will not push [it] for you," he grumbled. About ten percent of the content was left out after inspections, and port officials called Hodan to make him collect the surplus goods. Hodan dreaded this phone call, which implied that he lost the profit on the shipment and that his customers would wait longer for their goods to arrive. The system of containerization is predicated upon the stability of the relationships between its constituent elements (Martin, 2015). The practice of applying pressure unsettles this stability. Customs inspection no longer merely delays the container; it is a disruptive event that redefines the volume the container holds. As customs inspections undo the idea of the container as a fixed unit, the logistics agents' opportunities for value capture are lost.

Logistics agents take both spiritual and practical precautions to reduce the chances of customs inspection. The prosperity gospel - the belief that financial blessings are the will of God for Christians - is popular in African-led churches in South China, where the congregants are either accomplished or aspiring businesspeople. Prophesies, prayers, and testimonies often concern the smooth passing of containers. Pragmatic measures are also called for to protect the container. Logistics agents estimated that about one in ten containers leaving from the ports in Huangpu and Nansha were opened for inspection, with fluctuating interception rates. The fluctuation could be exploited to ensure the smooth passage of the 
containers. "It depends on [where] they are trying to be strict," Hodan replied when asked how he chose which port to use. He would call contacts in the ports before deciding where to direct a container truck. "This week there are a lot of checks," the liaison in Huangpu Port might say, in which case he would send the container to Nansha Port instead. At the national level, politicians want China to shed its global reputation as a source of copies and ensure compliance with international commitments (Zimmerman, 2013). Locally, by contrast, officials may place a higher priority on avoiding blockages in ports, ensuring that goods leave the manufacturing region unencumbered. The physical compression of commodities into bales and containers creates additional inducements for officials not to intercept containers, as well as for logistics agents to cultivate ties with officials.

\section{Conclusion}

Recently, attention to logistics has increased within political economy approaches to the global economy and is studied as an industrial complex in its own right (Coe, 2014). Placing analytic focus on the various sections of logistics operations draws attention to the wideranging set of resources that must be mobilized each time goods are moved across space. Demands for cost-effectiveness, increasing automation, and standardization in logistics have brought industry logistics deeper into the political and social realms. The space within containers provides a productive vantage point from which to study logistics as temporary social and political achievements that take on highly localized forms.

The introduction of the hydraulic baling machine in logistics from South China to African markets represented a creative adaption to the downward pressure on profits in the industry. Once it became part of the standard equipment employed by logistics agents, manufacturers were compelled to modify their products to ensure that they did not break under the baler's crushing force. Port authorities adapted to the practice of applying pressure to goods during loading by finding ways to limit how many pre-packed containers they opened for inspection to avoid surplus content spilling into the customs clearance area. The capillary pressure along the infrastructural chain to avoid disruptions led to a high political tolerance for disorder, with port safety ensured through personal relations between logistics agents and customs officers rather than through formal procedures. As is stressed through the logistics-in-action approach, optimization is actor- and network-specific (Gregson et al., 2017). The pressure exerted onto the goods leads to greater efficiency for logistics agents but creates other effects in different sections of the logistics chain. 
In intensely competitive and politically unpredictable environments, actors navigate on the edges of the doable. The practice of earmarking enables traders to hedge against volatility, which, in turn, allows them to create value in new ways. Whereas pressure allows the creation of marginal gains through lowering the cost of freight units, earmarking container space makes marginal gains possible by enabling traders to be conservative and risk-taking in their transactions simultaneously, ensuring they salvage some fraction of their capital if other parts are lost.

This research indicates that, from the perspective of those involved in exports from South China to African markets, the intensified commercial integration between China and African countries looks neither smooth nor inevitable. Moving goods and shifting money require considerable effort and creativity; thus far, the political acceptance of ad hoc solutions has been high. As the scale of the BRI and other Chinese-state-led logistics initiatives generate media and policy debates around the world, it is crucial to understand the localized and reversible nature of logistics integration.

\section{References}

A.T. Kearney. (2015) The 2015 Africa Retail Development Index. Available at: https://www.atkearney.com/documents/10192/6437503/Retail+in+Africa.pdf/b038891 c-0e81-4379-89bb-b69fb9077425 (accessed 10.10.2015).

Anand N. (2011) Pressure: The politechnics of water supply in Mumbai. Cultural Anthropology 26(4):542-564.

Bair J and Werner M. (2011) Commodity chains and the uneven geographies of global capitalism: a disarticulations perspective. Environment and Planning A 43(5):988-997.

Bertoncello B and Bredeloup S. (2007) The emergence of new African "trading posts" in Hong Kong and Guangzhou. China Perspectives 6(1):94-105.

Birtchnell T, Savitzky S and Urry J. (2015) Cargomobilities: moving materials in a global age, New York: Routledge.

Bohannan P. (1955) Some principles of exchange and investment among the Tiv. American Anthropologist 57(1):60-70.

Burawoy M and Verdery K. (1999) Uncertain transition: Ethnographies of change in the postsocialist world. Lanham: Rowman \& Littlefield.

Cantens T, Kaminski J, Raballand G, et al. (2014) Customs, brokers, and informal sectors: a Cameroon case study. World Bank Policy Research Working Paper (6788).

Chalfin B. (2010) Neoliberal Frontiers: an ethnography of sovereignty in West Africa, Chicago: University of Chicago Press.

Cidell J. (2015) Distribution centers as distributed places. In: Birtchnell T, Savitzky S and Urry J (eds) Cargomobilities: moving materials in a global age. New York: Routledge: pp. 17-34.

Coe NM. (2014) Missing links: Logistics, governance and upgrading in a shifting global economy. Review of International Political Economy 21(1):224-256.

Cowen D. (2010a) Containing insecurity: Logistic space, US port cities, and the "war on terror". In: Graham S (ed) Disrupted Cities: When Infrastructure Fails. New York: Routledge: pp. 69-83. 
Cowen D. (2010b) A geography of logistics: Market authority and the security of supply chains. Annals of the Association of American Geographers 100(3):600-620.

Cowen D. (2014) Disrupting Distribution: Subversion, the Social Factory, and the "State" of Supply Chains. Viewpoint Magazine 4:1-12.

Dalton G. (1965) Primitive Money. American Anthropologist 67(1):44-65.

Danyluk M. (2018) Capital's logistical fix: Accumulation, globalization, and the survival of capitalism. Environment and Planning D: Society and Space 36(4):630-647.

Feenstra R and Hanson G. (2004) Intermediaries in entrepôt trade: Hong Kong re-exports of Chinese goods. Journal of Economics \& Management Strategy 13(1):3-35.

Gregson N. (2017) Logistics at work: Trucks, containers and the friction of circulation in the UK. Mobilities 12(3):343-364.

Gregson N, Crang M and Antonopoulos CN. (2017) Holding together logistical worlds: Friction, seams and circulation in the emerging 'global warehouse'. Environment and Planning D: Society and Space 35(3):381-398.

Guyer JI. (2004) Marginal Gains: Monetary Transactions in Atlantic Africa, Chicago: University of Chicago Press.

Guyer JI, Khan N, Obarrio J, et al. (2010) Introduction: Number as inventive frontier. London: SAGE publications.

Haugen HØ. (2017) Petty commodities, serious business: the governance of fashion jewellery chains between China and Ghana. Global Networks 18(2):307-325.

Haugen HØ. (2018) From Pioneers to Professionals: African Brokers in a Maturing Chinese Marketplace. African Studies Quarterly 17(4):45-62.

Ho KC and So A. (1997) Semi-periphery and borderland integration: Singapore and Hong Kong experiences. Political Geography 16(3):241-259.

James D. (2014) Money from nothing: Indebtedness and aspiration in South Africa, Redwood City: Stanford University Press.

Jedlowski A. (2016) All for a container! Return migration, transport technologies, and love affairs. Transfers 6(2):94-111.

Kaika M. (2005) City of flows: Modernity, nature, and the city, London: Routledge.

Latour B. (1990) Visualisation and cognition: Drawing things together. In: Kuklick (ed) Knowledge and society studies in the sociology of culture past and present. Bingley: JAI Press: pp. 1-40.

Levinson M. (2016) The box: How the shipping container made the world smaller and the world economy bigger, Princeton: Princeton University Press.

Martin C. (2015) Cargomobilities: moving materials in a global age. In: Birtchnell T, Savitzky S and Urry J (eds) Cargomobilities: moving materials in a global age. New York: Routledge: pp. 65-86.

Mathews G. (2015) Taking copies from China past customs: Routines, risks, and the possibility of catastrophe. Journal of Borderlands Studies 30(3):423-435.

Mathews G, Lin LD and Yang Y. (2017) The world in Guangzhou: Africans and other foreigners in South China's global marketplace, Chicago: University of Chicago Press.

National Bureau of Statistics of China. (2017) China Statistical Yearbook 2017, Beijing: China Statistics Press.

Neilson B. (2012) Five theses on understanding logistics as power. Distinktion: Scandinavian journal of social theory 13(3):322-339.

Neilson B. (2015) A city that exports air. In: Birtchnell T, Savitzky S and Urry J (eds) Cargomobilities: moving materials in a global age. New York: Routledge: pp. 48-65.

Nordstrom C. (2007) Global outlaws: Crime, money, and power in the contemporary world, Berkeley: University of California Press. 
Parry J and Bloch M. (1989) Money and the morality of exchange, Cambridge: Cambridge University Press.

Refas S and Cantens T. (2011) Why does cargo spend weeks in African ports? The case of Douala, Cameroon. Available at: https://elibrary.worldbank.org/doi/pdf/10.1596/1813-9450-5565 (accessed 03.03.2017).

Rest M. (2018) Dreaming of pipes: Kathmandu's long-delayed Melamchi Water Supply Project. Environment and Planning C: Politics and Space:online first DOI: $10.1177 / 2399654418794015$.

Rose G. (1999) Performing space. In: Massey D, Allen J and Sarre P (eds) Human geography today. Cambridge: Polity Press: pp. 247-259.

Schwarz G. (2006) Enabling global trade above the clouds: Restructuring processes and information technology in the transatlantic air-cargo industry. Environment and Planning A 38(8):1463-1485.

Sigler TJ. (2013) Relational Cities: Doha, Panama City, and Dubai as 21st century entrepôts. Urban Geography 34(5):612-633.

Smart J and Smart A. (1991) Personal relations and divergent economies: a case study of Hong Kong investment in South China. International Journal of Urban and Regional Research 15(2):216-233.

Smith DJ. (2001) Ritual killing, 419, and fast wealth: inequality and the popular imagination in southeastern Nigeria. American Ethnologist 28(4):803-826.

Steinberg P. (2015) Maritime cargomobilities. The impossibilities of representation. In: Birtchnell T, Savitzky S and Urry J (eds) Cargo Mobilities. London: Routledge: pp. $35-47$.

Stenmanns J and Ouma S. (2015) The new zones of circulation: On the production and securitization of maritime frontiers in West Africa. In: Birtchnell T, Savitzky S and Urry J (eds) Cargomobilities: moving materials in a global age. pp. 87-105.

Swyngedouw E. (2004) Social power and the urbanization of water: Flows of power, Oxford: Oxford University Press.

Thaler R. (1985) Mental accounting and consumer choice. Marketing Science 4(3):199-214.

Thrift N. (1996) Spatial formations, London: SAGE Publications.

Tsing AL. (2009) Supply chains and the human condition. Rethinking Marxism 21(2):148176.

Tsing AL. (2015) The mushroom at the end of the world: On the possibility of life in capitalist ruins, Princeton: Princeton University Press.

UN Comtrade. (2018) International Trade Statistics database. Available at: https://comtrade.un.org/data/ (accessed 10.08.2018).

Wang JJ and Cheng MC. (2010) From a hub port city to a global supply chain management center: a case study of Hong Kong. Journal of Transport Geography 18(1):104-115.

World Bank. (2016) Connecting to compete. Trade logistics in the global economy. Available at: https://wb-lpi-media.s3.amazonaws.com/LPI_Report_2016.pdf (accessed 03.03.2017).

World Shipping Council. (2018) Global container fleet. Available at: http://www.worldshipping.org/about-the-industry/containers/global-container-fleet (accessed 26.09.2018).

Wyatt DJ. (2010) The blacks of premodern China, Philadelphia: University of Pennsylvania Press.

Zelizer VA. (1994) The social meaning of money, Princeton: Princeton University Press.

Zimmerman A. (2013) Contending with Chinese counterfeits: Culture, growth, and management responses. Business Horizons 56(2):141-148. 
